\title{
外場印加による粉体プロセスの進展 Development of powder processing under external fields
}

\author{
目 義雄 \\ Yoshio SAKKA \\ 物質・材料研究機構 \\ National Institute for Materials Science
}

新しい機能の付与や性能の向上のためには, 組織の微細化 が重要で，さらにナノサイズからミクロンサイズの粒径を持 つ組織の階層化, 傾斜化, 配向化が求められています，粉体 を出発としてこれらの要求を満たすためには, 粉体プロセス の高度化が必要です。粉体プロセスは，(1)粉体の合成，(2)粉 体表面処理と成形，(3)焼結，の過程を含む．それぞれの過程 に押いて，外場を印加することにより，プロセスの高度化が 試みられています，本特集では，粉体に応力を印加した改 質，超音波あるいはマイクロ波・ミリ波印加による特殊粒子 の作製，コロイド分散系に電場を印加して成形する電気泳動 堆積法，コロイド成形中に磁場を印加して配向体の作製，電 磁波を印加したパルス通電焼結やミリ波・マイクロ波燒結,

フラッシュ焼結，など様々な観点からの外場印加粉体プロセ スの発表を募集しました，本特集を通して，様々な外場を印 加することによる効果拉よびその機構を議論し，粉体プロセ スのさらなる高度化につながることを目指し, 企画・運営し ました。

本特集では, 36 件の発表（協会賞受賞講演，特別講演， 各 1 件, 招待講演 4 件を含む) が 1 日半かけて行われました。

初日の午後からのセッションでは, 液相加振法による硫化 物系リチウムイオン伝導性固体電解質の調製と全固体電池の 構築（松田，豊橋科技大）の招待講演に引き続き, ホーラン ダイト型複合酸化物イオン伝道, $\mathrm{Li}_{7} \mathrm{La}_{3} \mathrm{Zr}_{2} \mathrm{O}_{12}$ ナノ粒子の $\mathrm{Li}$ 電池への応用, 電気泳動による太陽電池用 $\mathrm{Ag}$ 分散膜や電池 正極複合体の作製，せん断場による六方晶窒化ホウ素の剥 離，溶解析出による炭化ケイ素プリカーサーの合成，外部駆 動力を利用した複合微粒子の規則配列構造体の作製， $\mathrm{AD}$ 法 による多機能セラミックス複合厚膜や $\mathrm{AD}$ 法の機構とアルミ ナ絶縁膜作製，に関する発表がありました。

2 日目の午前のセッションでは, 回転変調磁場を用いた希 土類系高温超伝導体の 3 次元結晶配向（堀井, 京大) の招待 講演に引き続き，酸化鉄配向体の作製と異方特性評価，パル 又磁場中の永久磁石粒子の運動解析, 紫外線硬化樹脂を用い た磁場中コロイド成形に関する発表. 休喤を挟んで，研究進
歩賞受賞記念講演として超音波・マイクロ波を利用した固液 系金属ナノ材料合成技術（林，東北大），マイクロ波加熱を 用いた Si-Ge 固溶体の作製や熱硬化性 CFRP の高速樹脂硬化 プロセス，相互拡散に抢よぼすミリ波照射の影響，水中レー ザーアブレーションによる $\mathrm{Y}_{2} \mathrm{O}_{3}: \mathrm{Eu}_{3+}$ 蛍光体ナノ粒子の合成, 液中プラズマ法により合成された $12 \mathrm{CaO} \cdot 7 \mathrm{Al}_{2} \mathrm{O}_{3}$ 系化合物 シリコンナノ結晶粒子のフォトルミネッセンスに関する発表 がありました。

午後からのセッションでは, 放電プラズマ燒結法（SPS/ ECAS）の特異現象と生产への応用（铇田, NJS）の特別講 演, 高圧を用いた $5 \mathrm{~d}$ 遷移金属窒化物硬質材料開発（川村, NIMS）の招待講演に引き続いて, パルス通電加圧法による 新規 $\mathrm{B}_{4} \mathrm{C} / \mathrm{CNF}$ 系コンポジット, MA-SPS 法による $\mathrm{Al}-\mathrm{Fe}$ 系磁 性材料, 反応 SPS による $\mathrm{B}_{4} \mathrm{C}$ 系軽量・高強度コンポジット, $\mathrm{AlN} / \mathrm{B} 4 \mathrm{C}$ や $\mathrm{B}_{4} \mathrm{C}-\mathrm{TiB}_{2}$ 系コンポジットコンポジットの作製, 評価に関する発表があった，休㮩を挟んで，酸化物セラミッ クスのフラッシュ焼結挙動と微細組織変化（吉田, NIMS) の招待講演に続き，直接通電焼結法による $\beta-\mathrm{FeSi}_{2}$ 熱電材料

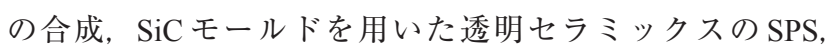
SPS により作製した Ti-Zr 基炭窒化物の相分離，SPSによる 高密度炭素ナノ構造体分散セラミック基ナノコンポジットの 作製， $\mathrm{SiC}$ 被覆バイモーダルダイアモンドの SPS 焼結，結晶 配向とSPSによるMAX 相セラミックス力学特性やAIN の熱 伝導性㧍よび透光性の向上，などSPSを利用した多様な発 表がありまた。

以上，様々な外場を印加することによる効果やその機構を 議論することができ，意義ある講演特集とすることができま した，共同提案者である鈴木達，西村聡之，打越哲郎（物 質 - 材料研究機構), 田中諭（長岡技術大）堀田裕司（産総 研), 多々見純一 (横浜国大), 武藤浩行（豊橋科学技術大） を代表してこの紙面を损借りして, 貴重な研究成果をご講演 して頂いた方々ならびに活発な議論にご協力いただいた方々 に心からお礼申し上げます。 